Bangladesh J. Plant Taxon. 28(2): 289-294, 2021 (December)

(C) 2021 Bangladesh Association of Plant Taxonomists

\title{
A NEW VARIETY OF ABRUS PRECATORIUS L. (FABACEAE) FROM BANGLADESH
}

\author{
Md. Abul Hassan, M. Oliur Rahman ${ }^{1}$ and Sumona Afroz ${ }^{2}$ \\ Department of Botany, University of Dhaka, Dhaka 1000, Bangladesh
}

Keywords: New variety; Abrus precatorius var. albo-spermum var. nov.; Fabaceae; Bangladesh.

\begin{abstract}
A new variety Abrus precatorius L. var. albo-spermum Hassan, Rahman et Afroz, var. nov. is described and illustrated from Bangladesh. The new variety is closest to Abrus preactorius L., but differs by its white coloured oval shaped seeds, short gynoecium which is half the length of longer filaments and with a short style.
\end{abstract}

\section{Introduction}

The genus Abrus (Fabaceae) was erected by Adanson in 1763 based on Glycine abrus L. (Breteler, 1960). Abrus Adans. is a small genus consisting of c. 17 species and widespread in tropical and subtropical regions predominantly in Asia, Africa and probably introduced in the New World (Munsuk et al., 2016). In Bangladesh, Abrus is represented by two species, viz. Abrus precatorius L. and A. pulchellus Wall. ex Thw. (Ahmed et al., 2009). Hooker (1876) in his Flora of British India reported A. pulchellus form Chittagong, whereas Prain (1903) documented A. precatorius and A. pulchellus from the present territory of Bangladesh. Abrus precatorius (redblack seeded form) is distributed almost throughout the country and occurs in diverse habitats including village thickets, natural forests and several protected areas of Bangladesh (Uddin et al., 2013; Rahman, 2017; Rashid et al., 2018). In contrary, Abrus pulchellus is rare and reported to be found in Chattogram, Cox's Bazar and Sylhet districts (Ahmed et al., 2009).

In early 2018, a group of botanists from the Department of Botany, University of Dhaka visited the Medicinal Plants Garden of Adhi Kabirj (an Ayurvedic physician) at the village Tok under Kapasia upazila of Gazipur district and collected different plant samples along with some seeds of 'Sada Kunch' (white Abrus). The white seeds of Abrus were grown in Dhaka University Botanical Garden for further investigation. Since then red-black seeded Abrus precatorius and purely white-seeded forms have been maintained alongside in the garden for comparison. The white-seeded taxon of Abrus displays some distinguishing characters, viz. gynoecium and seed characters which do not match with other known species of Abrus (Hooker, 1876; Prain, 1903; Kanjilal et al., 1938; Breteler, 1960; Deb, 1981; Ahmed et al., 2009; Wu et al., 2010; Munsuk et al., 2016). The white-seeded Abrus taxon is closely allied to the red-seeded Abrus precatorius in terms of stem, leaf, inflorescence and some floral characters; however, it differs from Abrus precatorius by gynoecium and seed characters. After critical examination, the white-seeded form of Abrus for its distinct, heritable and discontinuous characters, is recognized as a new variety, Abrus precatorius L. var. albo-spermum Hassan, Rahman et Afroz, var. nov.

\section{Results and Discussion}

Abrus precatorius L. var. albo-spermum Hassan, Rahman et Afroz, var. nov. (Fig. 1, Plate 1).

Diagnosis: Abrus precatorius L. var. albo-spermum Hassan, Rahman et Afroz, var. nov. is distinct by its entirely white seeds, gynoecium length which is half the length of the longer filaments and a short style.

${ }^{1}$ Corresponding author. Email: oliur.bot@du.ac.bd; prof.oliurrahman@gmail.com

${ }^{2}$ Present Address: National Museum, Shahbag, Dhaka 1000, Bangladesh 
Type: Bangladesh, Dhaka, Dhaka University Botanical Garden, M.A. Hassan 6001, 24 October 2021 (Holotype: DUSH!) (Originally seeds were collected from the village Tok of Kapasia upazila under Gazipur district and maintained in Dhaka University Botanical Garden since March 2018). The holotype is deposited at Dhaka University Salar Khan Herbarium (DUSH).

A handsome undershrub with twining stem, and on support grows as a dextrose climber. Leaves paripinately compound, alternate; leaflets linear or linear-oblong, usually 10-20 in number, occasionally more, opposite, very sweet in taste. Flowers in pedunculate racemes, shortly pedicellate, bisexual, complete; sepals 5, c. 2-4 mm long; petals 5, standard petal 10-11 × 7-8 mm, pinkish-white, wing petal 6-8 $\times$ c. $2 \mathrm{~mm}$, keel petal 7-8 $\times 3-4 \mathrm{~mm}$, elliptic; stamens 9 (alternately long and short, the vexillary filament absent). Gynoecium short, c. $2.5-3.5 \mathrm{~mm}$, half the length of longer filaments; style short, c. 0.5-0.8 mm long; carpel 1, placentation marginal. Fruits oblong pods, turgid, usually 4-6 seeded. Seeds purely white, oval, smooth.

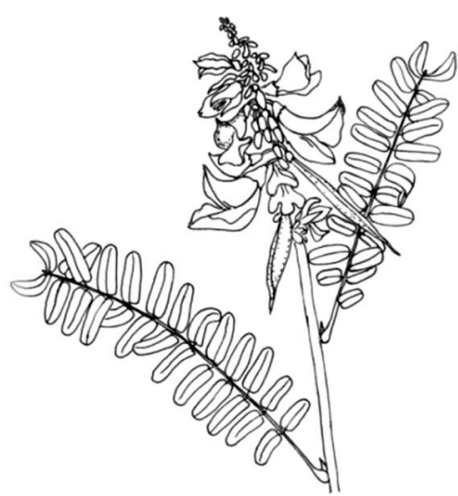

A

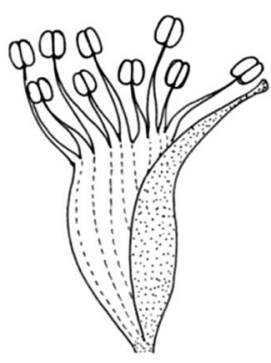

B

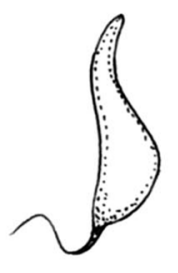

$\mathrm{C}$

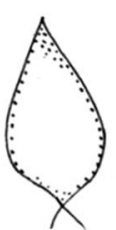

$\mathrm{D}$

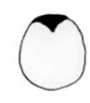

$\mathrm{E}$
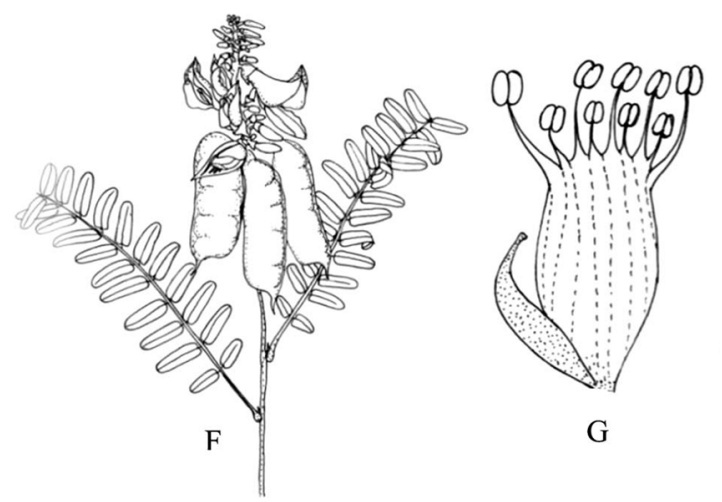

G

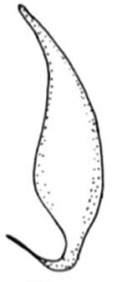

$\mathrm{H}$
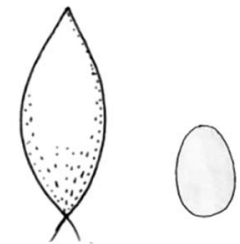

I

J

Fig. 1. A-E. Abrus precatorius; F-J: Abrus precatorius var. albo-spermum var. nov.; $\mathrm{A}, \mathrm{F}=\mathrm{Habit}$ sketch (x1); $\mathrm{B}, \mathrm{G}=$ Androecium vs. gynoecium (x5); C,H= Wing petal (x3); D,I= Keel petal (x3); E,J=Seed (x1). 

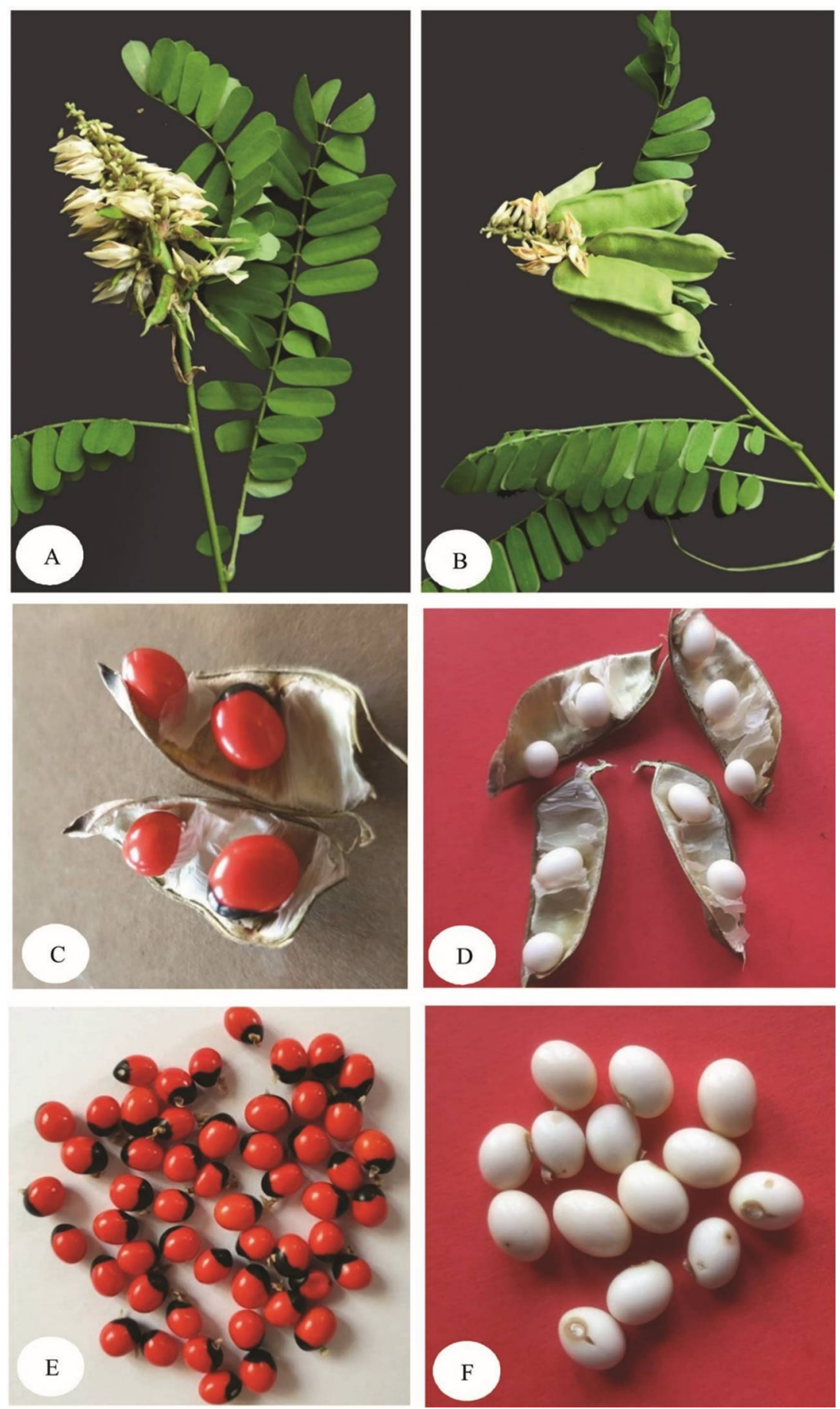

Plate 1. A, $\mathrm{C}, \mathrm{E}=$ Abrus precatorius; $\mathrm{B}, \mathrm{D}, \mathrm{F}=$ Abrus precatorius var. albo-spermum var. nov. A,B=Habit; C. $D=$ Fruits with seeds; E,F= Seeds. 
Flowering and fruiting: August to October.

Etymology: The new variety is named after the white colour of the seeds of the new taxon.

A comparative account of Abrus precatorius L. and the new variety Abrus precatorius var. albo-spermum Hassan, Rahman et Afroz, var. nov. are depicted in Table 1.

Table 1. Comparison of Abrus pracatorius L. and Abrus pracatorius var. albo-spermum Hassan, Rahman et Afroz, var. nov.

\begin{tabular}{|c|c|}
\hline Abrus precatorius $\mathrm{L}$. & $\begin{array}{l}\text { Abrus precatorius L. var. albo-spermum Hassan, } \\
\text { Rahman } \text { et Afroz var. nov. }\end{array}$ \\
\hline $\begin{array}{l}\text { 1. Seeds two-third scarlet and the rest jet-black, } \\
\text { almost round. }\end{array}$ & 1. Seeds entirely pure white, oval. \\
\hline 2. Gynoecium long, c. 6-7 mm. & 2. Gynoecium short, c. $2.5-3.5 \mathrm{~mm}$. \\
\hline $\begin{array}{l}\text { 3. Gynoecium more or less equal to length of longer } \\
\text { filaments. }\end{array}$ & 3. Gynoecium half the length of longer filaments. \\
\hline 4. Style long, c. $2.5-3.0 \mathrm{~mm}$ long. & 4. Style very short, c. $0.5-0.8 \mathrm{~mm}$ long. \\
\hline 5. Lower part of the wing petal narrower. & 5. Lower part of the wing petal broader. \\
\hline 6. Keel petal ovate. & 6. Keel petal elliptic. \\
\hline
\end{tabular}

Variation in seed colour: The new variety Abrus precatorius var. albo-spermum presents entirely pure white seeds, while the closely related Abrus preactorius displays variations in seed colour. In A. precatorius, seeds are usually two-third scarlet or white and the rest jet-black, sometimes whitish, rarely wholly black (Kanjilal et al., 1938); seeds scarlet with area around the hilum black, rarely entirely black, whitish or yellowish (de Padua et al., 1999); seeds bright scarlet and black or whitish black or mixed black and white (Bakshi et al., 1999); seeds red or white with a black cap (Panigrahi and Murti, 1989); seeds bright scarlet and black, or white, or mixed black and white (Hooker, 1876).

Seed germination: Ten seeds of Abrus precatorius var. albo-spermum var. nov. were sown on 20 March 2018 and out of 10 seeds sown only 3 seeds germinated on 25 March 2018, and the germination was found to be epigeal. A detailed study on seed germination of Abrus precatorius var. albo-spermum var. nov. and Abrus precatorius reveals that the process of seed development in both taxa is perhaps the same. However, in the last two weeks of seed maturation in the redseeded Abrus precatorius, colour development and colour changes occur. A black spot appears first at the hilum from where a reddish or pinkish colouration gradually coming down as observed on 26 September 2018. On 14 October 2018, it was observed that the black hilum portion became fully black (jet-black) and the lower part was yellowish-pink. After a few days the lower two-third yellowish-pink portion became scarlet when the seeds were fully mature. Therefore, the occasional whitish, yellowish, pinkish or fully black seeds found in the pods of Abrus precatorius might be due to incomplete final maturation process. A few fully black seeds were also noticed in the pods of this species; however, these black seeds did not germinate when sown.

Traditional uses and biological activities: The red-seeded Abrus precatorius and whiteseeded Abrus precatorius var. albo-spermum var. nov. both the taxa are traditionally used in treating different ailments. Seeds are purgative, emetic and aphrodisiac, and administered in the treatment of diarrhoea and dysentery. In Ayurvedic medicine, especially the white-seeded form is used as they are thought to be less toxic (Panigrahi and Murti, 1989; Pal and Jain, 1998). Abrus precatorius leaf is used as laxative, expectorant and aphrodisiac in Ayurvedic medicine (Bhakta and Das, 2020). Leaves are applied to cure fever, cough and cold, while the roots are used to treat jaundice and haemoglobinuric bile (Garaniya and Bapodra, 2014). Seed extract is CNS depressant 
and reported to have antibacterial and analgesic properties (Yusuf et al., 2009). Various pharmacological study reveals that Abrus precatorius possesses anti-oxidative (Arora, 2011), neuroprotective (Premanand and Ganesh, 2010), anti-depression (Attal et al., 2010), antiinflammatory (Kuo et al., 1995) and anticancer (Anbu et al. 2011) activities. Very recently, antiulcerative efficacy of ethyl acetate extract of Abrus precatorius seed in hydrochloric acid/Ethanol $(\mathrm{HCl} / \mathrm{EtOH})$-induced ulcerative rats via regulation of inflammatory genes has been determined (Omoboyowa et al., 2021).

\section{References}

Ahmed, Z.U., Hassan, M.A., Begum, Z.N.T. Khondker, M., Kabir, S.M.H., Ahmad, M., Ahmed, A.T.A. (Eds), 2009. Encyclopedia of Flora and Fauna of Bangladesh, Vol. 8. Angiosperm: Dicotyledons (Fabaceae- Lythraceae). Asiatic Society of Bangladesh, Dhaka, 478 pp.

Anbu, J., Ravichandiran, V., Sumithra, M., Chowdary, S.B., Kumar, S., Kannadhasan, R. et al. 2011. Anticancer activity of petroleum ether extract of Abrus precatorius on ehrlich ascitis carcinoma in mice. Int. J. Pharm. Biol. Sci. 2: 24-31.

Arora, R. 2011. Phytopharmacological evaluation of ethanolic extract of the seeds of Abrus precatorius L. J. Pharmacol. Toxicol. 6(6): 580-588.

Attal, A.R., Otari, K.V., Shete, R.V., Upasani, C.D. and Nandgude, T.D. 2010. Abrus precatorius Linnaeus: a phytopharmacological review. J. Pharm. Res. 3(11): 2585-2587.

Bakshi, D.N.G., Sensarma, P. and Pal, D.C. 1999. A Lexicon of Medicinal Plants in India, Vol. 1. Naya Prokash, Calcutta, India, 552 pp.

Bhakta, S. and Das, S.K. 2020. The medicinal values of Abrus precatorius: a review study. J. Adv. Biotechnol. Exp. Ther. 3(2): 84-91.

Breteler, F.J. 1960. Revision of Abrus Adanson (Pap.) with special reference to Africa. Blumea 10(2): 607-624.

de Padua, L.S., Bunyapraphatsara, N. and Lemmens, R.H.M.J. (Eds) 1999. Plant Resources of South-East Asia No. 12(1). Medicinal and Poisonous Plants. Backhuys Publishers, Leiden, the Netherlands, 711 pp.

Deb, D.B. 1981. The Flora of Tripura State, Vol. 1 (Ophioglossaceae - Staphyleaceae). Today \& Tomorrow's Printers \& Publishers, New Delhi, India, 509 pp.

Garaniya, N. and Bapodra, A. 2014. Ethnobotanical and phytophrmacological potential of Abrus precatorius L.: A review. Asian Pac. J. Trop. Biomed. 4 (Suppl. 1): S27-S34.

Hooker, J.D. 1876. Flora of British India, Vo. 2. L. Reeve \& Co. Ltd., Kent England, p. 175.

Kanjilal, U.N., Kanjilal, P.C. and Das, A. 1938. Flora of Assam, Vol. 2. A Van Book Company, Delhi, India, $409 \mathrm{pp}$.

Munsuk, W., Chantaranothai, P. and Kongsook, B. 2016. The genus Abrus Adans. (LeguminosaePapilionoideae) in Thailand. Trop. Nat. Hist. 16(2): 67-77.

Kuo, S.C., Chen, S.C., Chen, L.H., Wu, J.B., Wang, J.P. and Teng, C.M. 1995. Potent antiplatelet, antiinflammatory and antiallergic isoflavanquinones from the roots of Abrus precatorius. Planta Medica 61: 307-312.

Omoboyowa, D.A., Omomule, O.M., Balogun, T.A., Saibu, O.A. and Metibemu, D.S. 2021. Protective potential of ethyl acetate extract of Abrus precatorius (Linn) seeds against $\mathrm{HCl} / \mathrm{EtOH}$-induced gastric ulcer via pro-inflammatory regulation: In vivo and in silico study. Phytomedicine Plus 1(4): 100145.

Pal, D.C. and Jain, S.K. 1998. Tribal Medicine. Naya Prokash, Bidhan Sarani, Calcutta, 317 pp.

Panigrahi, G. and Murti, S.K. 1989. Flora of Bilaspur District, Vol. 1 (Ranunculaceae - Convolvulaceae). Botanical Survey of India, 396 pp.

Prain, D. 1903 (Reprinted 1981). Bengal Plants, Vol. 1. Bishen Singh Mahendra Pal Singh, Dehra Dun, India, p. 369.

Premanand, R. and Ganesh, T. 2010. Neuroprotective effects of Abrus precatorius Linn. aerial extract on hypoxic neurotoxicity induced rats. International J. Chem. Pharmac. Sci. 1(1): 9-15. 
Rahman, M.A. 2017. Plant diversity in Hazarikhil Wildlife Sanctuary of Chittagong and its conservation management. J. Biodiver. Conserv. \& Bioresour. Manag. 3(2): 43-56.

Rashid, M.H., Islam, S. and Kashem, S.B. 2018. Floristic diversity (Magnoliids and Eudicots) of Baraiyadhala National Park, Chittagong, Bangladesh. Bangladesh J. Plant Taxon. 25(2): 273-288.

Uddin, M.Z., Alam, M.F., Rahman, M.A. and Hassan, M.A. 2013. Diversity in angiosperm flora of Teknaf Wildlife Sanctuary, Bangladesh. Bangladesh J. Plant Taxon. 20(2): 145-162.

Wu, Z.Y., Raven, P.H. and Hong, D.Y. (Eds). 2010. Flora of China, Vol. 10 (Fabaceae). Science Press, Beijing, and Missouri Botanical Garden Press, St. Louis, 577 pp.

Yusuf, M., Begum, J., Hoque, M.N. and Chowdhury, J.U. 2009. Medicinal Plants of Bangladesh. Bangladesh Council of Scientific and Industrial Research Laboratories Chittagong, Bangladesh, 794 pp.

(Manuscript received on 3 July 2021; revised on 4 December 2021) 